\title{
Relational Struggles and Experiential Immediacy in Religious American Families
}

\author{
David C. Dollahite \\ Brigham Young University, david_dollahite@byu.edu \\ Loren D. Marks \\ Brigham Young University - Provo, loren_marks@byu.edu \\ Kaity Pearl Young \\ Utah State University
}

Follow this and additional works at: https://scholarsarchive.byu.edu/facpub

Part of the Other Social and Behavioral Sciences Commons

\section{Original Publication Citation}

Dollahite, D. C., Marks, L. D., \& *Young, K. P. (2019). Relational struggles and experiential immediacy in religious American families. Psychology of Religion and Spirituality, 11, 9-21.

\section{BYU ScholarsArchive Citation}

Dollahite, David C.; Marks, Loren D.; and Young, Kaity Pearl, "Relational Struggles and Experiential Immediacy in Religious American Families" (2017). Faculty Publications. 4833.

https://scholarsarchive.byu.edu/facpub/4833

This Peer-Reviewed Article is brought to you for free and open access by BYU ScholarsArchive. It has been accepted for inclusion in Faculty Publications by an authorized administrator of BYU ScholarsArchive. For more information, please contact ellen_amatangelo@byu.edu. 


\title{
Relational Struggles and Experiential Immediacy in Religious American Families
}

\author{
David C. Dollahite and Loren D. Marks \\ Brigham Young University
}

\author{
Kaity Pearl Young \\ Utah State University
}

\begin{abstract}
Qualitative family scholar Kerry Daly has called for more theory addressing understudied dimensions including religion, everyday experiences, and time. Herein we address all three of these dimensions as we empirically examine and theorize on relational struggles among religious families. We also explore what we term experiential immediacy_-defined as the personal and temporal proximity to participantreported lived experience. Based on qualitative analyses of in-depth interviews with 198 highly religious families $(N=476$ individuals), we identified four types of relational struggles created by religious involvement: burdens, disunities, abuses, and offenses. We also offer a conceptual framework of experiential immediacy grounded in the findings and explore how personal and temporal immediacy of remembered, present, and possible experiences and quality of experience relate to relational struggles created by religious involvement. We also suggest implications for research based on our findings and concepts.
\end{abstract}

Keywords: experiential immediacy, family, qualitative, religion, struggles

Qualitative family scholar Kerry Daly has called for more theory addressing understudied dimensions including religion, everyday experiences, and time (Daly, 2004). Herein we address these three dimensions as we empirically examine and theorize on relational struggles and experiential immediacy among religious families. Based on our qualitative analyses of the ways that participants discussed relational struggles vis-àvis religious involvement, we constructed a set of ideas around a concept we call experiential immediacy-defined as the personal and temporal proximity to participant-reported lived experience.

Religion both helps and harms individuals and families as illustrated in history, contemporary events, and the personal experience of those who engage in lived religion. For example, a large body of research indicates that religion helps individuals by typically promoting individual-level mental and physical

This article was published Online First November 30, 2017.

David C. Dollahite and Loren D. Marks, School of Family Life, Brigham Young University; Kaity Pearl Young, Department of Family, Consumer, and Human Development, Utah State University.

We appreciate research funds from the BYU Academic Vice President's Office and the College of Family, Home, and Social Sciences. We appreciate Hilary Dalton for coordinating the coding process and Julia Norman, Ashley Tuft, Katelyn Ray, Jennifer Hamula, Lindsey Feil, and Amy Dayeong for coding assistance. Kaity Pearl Young (third author) was involved in coding or checking the coding on many of the 198 interviews. We appreciate helpful comments on a previous draft by Hilary Dalton, Mary Dollahite, Betsy Hughes, and Nathan Jorgensen and statistical assistance from Nathan Jorgensen, Spencer Dollahite, and Sterling Hilton.

Correspondence concerning this article should be addressed to David C. Dollahite, School of Family Life, Brigham Young University, 2092B JFSB, Provo, UT 84602. E-mail: david_dollahite@byu.edu heath (Koenig, King, \& Carson, 2012)—and that religious involvement seems to benefit couples and families in a variety of ways including promoting marital stability, forgiveness, conflict resolution, and resiliency in the face of stress (Bengtson, Putney, \& Harris, 2013; Burr, Marks, \& Day, 2012; Marks \& Dollahite, 2017; Pargament, 2013; Simonič, Mandelj, \& Novsak, 2013; Stark, 2012). On the other hand, religion can harm individuals and families when, for example, it (a) leads people to experience guilt, repression, and hypocrisy; (b) promotes passive fatalism; (c) creates gender inequities in marriage, family, and society; (d) encourages irrational and/or "magical" thinking; (e) enables sexual, emotional, physical, and/or financial victimization and abuse of children and other vulnerable persons; (f) fosters moral arrogance, elitism, and/or bigotry in believers, and/or is ( $\mathrm{g}$ ) is employed as a destructive force or weapon (i.e., the Inquisition, the Pogroms, the Crusades, the Holocaust, terrorism, Jihad; Dollahite, Marks, \& Young, in press).

Recent theoretical and empirical work has explored the dualities inherent in religion and its associations with both great good and great harm (Dollahite et al., in press; Pargament, Mahoney, Exline, Jones, \& Shafranske, 2013; Pargament, 2002). Furthermore, religion can have divergent influences on family relationships (Mahoney, 2010; Mahoney, Pargament, Tarakeshwar, \& Swank, 2001). For example, religion (a) both unites and divides families, (b) is both conservative and transformative in families, (c) both specifies expectations and provides comfort and support to families, and (d) both excites and calms passions in families (Dollahite et al., in press).

One phenomenon we have recently identified and explored is the duality that religion both generates and addresses what we call relational struggles in families. In this article, we investigate the first half of this duality - that religion can generate some relational 
struggles. Our findings indicate that relational struggles are ubiquitous among our diverse sample of highly religious families, including those that are privileged in various ways.

\section{Review of the Literature}

We are family scholars who employ qualitative methods to study the nexus (intersection) of religion and family relationships-particularly among highly religious families (Marks \& Dollahite, 2011, 2017). In our in-depth interviews, we ask broad questions about what religious families see as connections between their faith and their family life. Our own conceptual and empirical work on relational struggles has emerged only in the last couple years as the result of having conducted a new series of analyses of our interview data after it became clear that our highly religious participants repeatedly indicated that they experienced a variety of relational struggles associated with their religious involvement.

Thus, only recently did we become aware of Julie Exline's excellent psychologically oriented work on religious struggles. Unfortunately, because we were not aware of this work when we began our ongoing research project in 2001, our interview questions were not informed by this body of research and theory. Below we briefly review this line of scholarship and how it relates to our work, as well to other work done by family scholars on religious families.

\section{Religious and Spiritual Struggles}

Religious and spiritual struggles have been said to "occur when some aspect of R/S [Religious/Spiritual] belief, practice, or experience becomes a focus of negative thoughts or emotions, concern or conflict" (Exline, Pargament, Grubbs, \& Yali, 2014, p. 208). The literature on religious and spiritual struggles addresses three main domains: (a) divine (e.g., anger toward God), (b) intrapersonal (e.g., feeling unworthy because of religious reasons), and (c) interpersonal (e.g., conflict between members of a congregation). Various religious struggles have been associated with undesirable mental and physical health outcomes (Abu-Raiya \& Pargament, 2015; Exline, 2013; McConnell, Pargament, Ellison, \& Flannelly, 2006).

Empirical studies of religious and spiritual struggles have focused mainly on negatively perceived relationships with God or "the divine domain" (Exline, 2013). Comparatively little research exists in the intrapersonal and interpersonal struggles domains. Research on intrapersonal struggles has included feelings of guilt or struggling to follow religious moral standards (Exline \& Rose, 2013). Interpersonal struggles studies have focused on relationships with those outside the family, such as with fellow congregants (Krause, Chatters, Meltzer, \& Morgan, 2000). Other research has examined the effects of religion on parenting and marriage relationships, some of which reveals struggles that religion can generate in family relationships (see Mahoney, 2010, 2013).

\section{Religious Struggles and Family Relationships}

According to Exline's (2013) review, most of the literature on religious struggles examines mental and physical health outcomes. Likewise, many studies focus on a group with a particular stressor (e.g., cancer patients; e.g., Abu-Raiya, Pargament, Krause, \& Ironson, 2015), or on one domain of struggle (either intrapersonal, interpersonal, or divine; Ellison \& Lee, 2010). However, some studies have found negative outcomes of religion and spirituality on family relationships. Although these studies do not focus on struggles, their findings suggest the ways that families may be affected negatively by their religion or spirituality.

Previous research has shown that differences in religious beliefs tend to generate conflict in marriage relationships (Curtis \& Ellison, 2002) and that shared beliefs are important in maintaining strong marriages (Robinson \& Blanton, 1993). Differing beliefs or levels of religious commitment may also lead to conflict in parentchild relationships (Stokes \& Regnerus, 2009). Furthermore, conflicting levels of religious involvement between parents can also be a challenge in marriage, even when denomination is shared ( $\mathrm{Lu}$, Marks, \& Apavaloiae, 2012). Religion can also generate division within extended families between those in the same faith and those in another-or in no faith at all.

Research has also shown that compulsory family worship may have negative effects (Lee, Rice, \& Gillespie, 1997). Religious parents may be more authoritarian than others in their parenting style (Ellison, Bartkowski, \& Segal, 1996). However, scholars have typically correlated religiosity with authoritative (high warmth, high control) parenting, while aspects of authoritarianism were negatively correlated with religiosity (Ellison et al., 1996; Gunnoe, Hetherington, \& Reiss, 1999). Other research has shown that believing that God sanctions violence may lead religious persons to behave more aggressively (Bushman, Ridge, Das, Key, \& Busath, 2007; Sacks, 2015).

\section{Relational Struggles in Religious Families}

In short, work by Exline and other scholars tends to focus on how struggles with various aspects of one's religion influences individual-level social and psychological outcomes, whereas our work on relational struggles in religious families focuses on the ways that religious belief, practice, and community can lead to relational challenges within families. Despite the somewhat different foci of our work, there are important points of connection and we have found it helpful to consider several apparent links. Although we do not suggest that the relational struggles we study are considerably different than the interpersonal religious struggles studied by Exline and others, we hope that our approach to the study of relational struggles in religious families can contribute to this literature. In sum, our work presents a different unit of analysis: the family.

\section{The Current Study}

Because our work addresses the nexus of religion and family relationships, we chose to focus our attention on struggles involving family relationships (relational struggles). This study explores types of relational struggles associated with religious involvement that highly religious families reportedly experience. We also examine whether these types differ from the domains identified in previous research on family relationships and religious struggles. We identified data excerpts as examples of Relational Struggles Associated with Religion. Further, this article focuses solely on within-family relational struggles- 
relational struggles reported as arising within the immediate or extended family. We also connect our findings to a conceptual model of how experiential immediacy interacts with relational struggles among religious families.

Thus, our study sought to discover different types of relational struggles. Rather than focusing on outcomes or one particular struggle, we sought to discover different types of struggles only. The present study adds to research addressing religiously oriented struggles among racially diverse, national, and multidenominational samples. Our highly religious sample also allows us to see how religious involvement may influence the perceived nature of religious and spiritual struggles.

\section{Reflexivity}

Reflexivity refers to the practice of scholars reflecting and reporting how they believe their own experiences, prejudices, assumptions, agendas, and other sources of bias may have influenced various aspects of their research — and, ideally, what they did to try to address such biases (Daly, 2007). Accordingly, we note that all three authors are active participants in our faith communities. Based on our own beliefs and experiences and on the growing body of research highlighting the ways religion strengthens marriage and family relationships, we are predisposed to focus on ways that religion can benefit individuals and families. These biases need to be addressed and, to the degree possible, checked or countered. The present article is a part of a sustained and systematic effort to challenge and counter our own native biases by actively seeking for and reporting data regarding how and why religion can harm or generate struggles in family relationships.

\section{Method}

\section{Participants}

Participants are drawn from the American Families of Faith project (Please see Table 1 for a detailed comparison of the strengths and weaknesses of different approaches to research and for methodological strengths of the present study. For more information about the project, see http://AmericanFamiliesofFaith.byu .edu). Purposive sampling methods were used (Denzin \& Lincoln, 1994). After receiving IRB approval, clergy were contacted and asked to identify strong, marriage-based families with children who were committed to and involved in their faith. Second, recommended families were contacted to determine willingness to

Table 1

Comparison of Methodological Strengths and Benefits of Current Study With Other Approaches

Gold standard quantitative social science research:

1. Based on large samples (e.g., thousands of participants) thus, there is sufficient statistical power to conduct high confidence comparisons between groups.

2. Nationally representative samples thus can be generalized to the broader U.S. population.

3. Examines (and/or control for) many different factors/variables (often 10+) thus provides a broad picture of "what is going on."

4. Longitudinal method allowing comparison of measures across time to establish causality.

Two key limitations of this research include the realities that it:

1. Is often limited to reports from one person per family (Handel, 1996).

2. Is often limited to survey responses without fielding participants' in-depth verbal responses, contextualizing comments, narratives, or explanations

Most Qualitative Family Research:

1. Based on small samples of fewer than 30 participants.

2. Based on racially and culturally homogenous samples without comparison groups (e.g., white Jewish women).

3. Conducted within a limited cultural/geographic area, based on researcher convenience.

4. Involves only one participant per family (Handel, 1996).

5. Conducted primarily or solely by one or two researchers, whose biases go unchecked.

Two key limitations of this research include the realities that it:

1. Often provides unique depth — but is limited by constrained sample size, limited scope, and questionable applicability.

2. Further, the above limitations leave most qualitative studies vulnerable to criticisms regarding validity, reliability, and replicability.

The American Families of Faith Qualitative Research Project:

1. Based on sample of 476 participants from 198 families collected through a replicable sampling strategy (recommendations from religious gatekeepers)

2. Heterogeneous sample characterized by: 2A) Rich racial/ethnic diversity (50\%+ of the sample); including African American, Asian American, Latino, Native American, Middle Eastern, East Indian, and Pacific Islander families. 2B) Religious diversity (more than 20 Christian, Jewish, and Muslim denominations) 2C) Socio-economic diversity (educational experience ranged from GED-PhD/MD)

3. Based on a national (although not nationally representative) sample that includes participants from 17 states in all eight religio-cultural regions of the United States (see Silk \& Walsh, 2011).

4. Includes in-depth, interview-based questioning of multiple participants per family [mother, father, child(ren)], consistent with Handel's (1996) call for true "family" research.

5. Involved $100+$ diverse researchers/coders to provide data audit trails, checks, balances, and inter-rater reliability for reported themes (see Marks, 2015 for discussion).

6. Face-to-face, in-depth interviews (2-4 hours) in the homes and worship places of families (as opposed to phone or online interviews).

7. The sample consists of "exemplars" of both religious involvement and family strength achieved by inviting religious gate keepers to recommend known exemplars.

8. "Trans-Historical" in that data collection occurred from 2001-2015. Sample not limited by historical events such as 9-11, the housing collapse of 2008, natural disasters (e.g., hurricanes Katrina and Rita), and the presidential elections of 2004, 2008 , and 2012.

Note. Table adapted from http://AmericanFamiliesofFaith.byu.edu 
participate. Among more difficult-to-access faiths (e.g., Islam, Orthodox Judaism), participant referral sampling was sometimes employed.

Given their level of attendance (most at least weekly), monetary contribution (about $7 \%$ of income), and hours spent in religious service, and given that families were recommended by their religious leaders as being "strong in their faith" and "successful ... in their family relationships," we consider this sample of interviewed families to be exemplars.

We purposively sampled religious families in a two-stage selection process and oversampled racial and ethnic minority families and immigrants. Ethnic/Minority families comprise more than half of the overall sample of 198 families ( $N=476$ individuals). The sample includes, but is not limited to, African American, Asian American, East Asian, Latino, Middle Eastern, Native American, and Pacific Islander families. The sample includes 148 Christian families (from more than 15 denominations), 30 Jewish families (including Hasidic, Modern Orthodox, Conservative, and Reformed), and 20 Muslim families (including Sunni and Shia).

Geographically, participant families are from 17 states in all 8 major regions in the nation, including the following: Mid-Atlantic (DE, MD, PA), Midwest (OH, WI), Mountain West (ID, UT), New England (MA, CT), Northwest (OR, WA), Pacific (CA), the South/ Gulf Coast (FL, GA, LA), and Southern Crossroads regions (KS, OK). Further, the families represented a wide range of socioeconomic and educational levels. Thus, the sample is characterized by: (a) a generally high level of religious commitment, (b) rich racial and ethnic diversity, (c) religious diversity, (d) geographic and regional diversity, and (e) a wide range of socioeconomic status.

Handel (1996) has indicated that family research is often based on a single individual representing the family, but he contends that this is not "family research" in the truest sense. Handel has stated, "No [single] member of any family is a sufficient source of information for that family" (p. 346). In the present study, mothers, fathers, and (in 55 families) children were interviewed to gather multiple perspectives on a variety of relationships in the immediate and extended family.

\section{Interviewing}

We wanted to explore both successes and challenges that religious families actually experience, therefore intensive interviewing was chosen as an appropriate method. We strove to address and check our biases in the interviewing processes as well. Each interview question was pretested to identify any potential problems. Each question was open-ended, and many had follow-up questions to clarify and add depth to the initial responses given. No questions directly asked about how religion specifically was associated with relational struggles because our decision to explore this question in depth came after we had gathered the data. However, to counter our proreligion biases we asked the question, "Do you feel that there are any religious beliefs or practices that, if misunderstood or misapplied, can be harmful to marriage? If so, what are they?" Perhaps because we used the word "can," many of the responses to this question were hypothetical examples. Other interview questions focused on participants' religious beliefs, religious practices, religious communities, marital relationships, and family life.
Participants referred by clergy were unknown to the interviewers with six exceptions (6 of 198 families; 3\%). The first and second authors conducted about half of the interviews. The rest were conducted by graduate students. Interviewers were trained to follow a set of procedures to provide consistency across interviews and followed a semistructured interview format. Married couples were first interviewed (husband and wife present without children) and then, in the 55 families where adolescent children were also interviewed, parents and children were interviewed together. Although this interview methodology may introduce some potential limitations, such as spouses not fully sharing because their spouse is present or adolescents not sharing their full opinion because parents are present, it also allowed for the interviewer to observe the family dynamics, and the family-based interview sheds light on some of the religious context in which the adolescents live.

Interviews were conducted as a couple. Babbie (2004) stated that joint interviews "frequently brings out aspects of the topic that would not have been anticipated by the researcher and would not have emerged from interviews with individuals" (p. 303). Seymour, Dix, and Eardley (1995) argued that joint interviewing reveals different kinds of knowledge held by each person and produces more complete data as persons fill in each other's gaps and memory lapses.

Many scholars advocate interviewing spouses separately so as to (a) encourage greater honesty and (b) be sensitive to gender and power issues (Seymour et al., 1995). These are important issues and we concur that this is often a better approach. However, interviewing couples together also allows spouses to complement each other's perspectives and respects diverse cultural and religious beliefs and practices regarding opposite gendered individuals being alone (as was the case for Muslim, LDS, and some Orthodox Jewish couples).

Yet this approach is limited in that some wives or husbands may not have been fully open about their experiences or feelings. To address this, the interviewer encouraged wives and husbands to respond to each question and to comment on or add to the other's response. Interviews included much interchange, correcting, challenging, and adding to spouse's comments. Consistent with research involving couple interviews conducted by Holmberg, Orbuch, and Veroff (2004), the wives corrected or added to comments made by their spouse more often than husbands. Most interviews were about two hours in length. The interviews were transcribed verbatim and coded as explained in the next section.

\section{Coding and Analyses}

We employed a team-based approach to qualitative data analysis and coding [for extensive explanation, see Marks (2015)]. Our ethnically and nationally diverse six-member coding team included Asian American, European American, Polynesian American, and (native) German members. Our teambased approach integrates several strategies for producing "valid, reliable, and rigorous qualitative research" (Marks, 2015, p. 494), including: (a) developing a detailed audit trail for sampling, questionnaire usage, and qualitative coding that demonstrate and provide a "replicable method of inquiry" (p. 499); (b) building a qualitative research team that engages "team members with a diversity of project-relevant life experience ... [in order to heighten] sensitivity to diversity of experience in 
the participants' lives" (p. 499); and (c) coding the data as a team with a focus on interrater reliability in a way that allows for multiple voices but "tempers the idiosyncrasies [and biases] of any single member" (p. 502). Ultimately, only themes that achieve consensus are "designated with the carefully reserved appellation of core theme" (p. 503, emphasis in original).

We use the term accounts to refer to thoughts and experiences shared by participants. We constructed a detailed codebook to search the data systematically, thoroughly, and rigorously to find any accounts of relational struggles associated with religion reported in the more than 4,200 single-spaced pages of transcribed interviews. Coders were instructed to look for accounts of struggles associated with religion, including profound struggles (e.g., those pertaining to death, salvation, anomie, and meaninglessness) as well as more common and "everyday life" struggles_past, present, or future (Daly, 2004). We used a rigorous team-based coding strategy, which resulted in a composite interrater reliability of .94 for the "religion related relational struggles" codes. Specifically, our team coded 1,453 accounts of how religion is associated with relational struggles. Our focus was on struggles that seemed to directly relate to the quality or stability of relationships that we term Relational Struggles Associated with Religion. Of the 1,453 accounts, 282 (19\%) involved "within-the-family struggles." We examine these 282 family centric struggles accounts indepth in the present article. Based on our qualitative analyses, we have identified by consensus four types of relational struggles (under the four core themes of burdens, disunities, abuses, and offenses).

The latter process is called theoretical coding because we defined the construct of Relational Struggles Associated with Religion and constructed a theory-testing codebook and coding process to identify examples in the data. Consistent with the aims of various qualitative approaches (Denzin \& Lincoln, 1994), we also have constructed theoretical concepts grounded in analyses of our data.

\section{Experiential Immediacy}

Based on our qualitative analyses of the ways that participants discussed relational struggles in relation to religious involvement, we constructed a set of ideas around a concept we call experiential immediacy - defined as the personal and temporal proximity to the lived experience expressed by participants. In brief, the experiential immediacy concept refers to two dimensions: (a) temporal proximity - whether an experience reported by a respondent took place in the remembered past, the present, or involved a possible experience (a hypothetical or envisioned future experience), and (b) personal proximity - whether the experience was personal or familial.

This empirical exploration and conceptual consideration led to the construction of the experiential immediacy concept that we discuss in detail (and illustrated in Figure 1) following our presentation of the identified relational struggles. Thus, we have employed a two-stage approach to connecting theory with our data-first, a deductive approach (theoretical coding to identify relational struggles associated with religion) and second, an inductive approach (grounded theory on relational struggles and experiential immediacy).

\section{Findings on Relational Struggles}

Our analyses yielded four types of relational struggles: burdens, disunities, abuses, and offenses. Table 2 presents the number of coded accounts reflecting these core themes, across actual and possible experiences, in the order of most to least frequently occurring. As we present accounts of each of the four struggles below, we indicate the temporal and personal proximity in brackets before each account (e.g., [present personal] or [past familial]).

\section{Relational Struggle 1: Burdens}

Participants' accounts of burdens often seemed more intrapersonal than the other accounts, but were included because they reflect participants' feelings of failure and inadequacy in fulfilling religious expectations pertaining to relationships, and the pressures of being obligated with religious responsibilities concerning relationships. Thus, they included both an intrapersonal and an interpersonal dimension. The struggles coded as burdens were the most frequently occurring (accounting for $38 \%$ of the within-family Relational Struggles Associated with Religion data). Burdens were also the struggle that was most concentrated in the present $(60 \%$ of burdens accounts were "present"). Chi-square analyses suggest this was significantly more than expected at random (see Table 2). Burdens included two subcategories: inadequacies and obligations, which are addressed and illustrated next.

Inadequacies: "We fall short all the time." The inadequacies struggles reflected expressions by the participants regarding worry about failure, or actual failure, to fulfill religious responsibilities and expectations - or failure to be a good example to family members. Included were expressions of parents talking about their children not living up to religious standards or about making unduly high demands of their children. Also included were expressions about accountability to God regarding family relationships. Religious requirements of relationships included how family members were expected to interact with and/or teach other family members, especially children. Pati ${ }^{1}$, a Pentecostal Native American, expressed difficulty in living up to expectations to raise her children with religious teachings [present familial]:

\footnotetext{
The Bible says to "train up a child in the way he should go and when he is older he will not depart from it." We try to make sure that we show . . . our children the principles of God and the way that God would handle things. We fail constantly. We fall short all the time and we're just like any other parents. Sometimes ... we do not know if we're doing the right thing or not. We struggle with this, what we should or shouldn't do. It's hard, 'cause especially if they're getting older, they're wanting to go . . . their own way. . . . Trying to keep them under God's word and the way that He would have you to do it, it's pretty essential [but it's hard].
}

Elsu (husband) and Wachiwi (wife), Christian Native Americans, similarly explain how they are accountable for whether or not their children are Christian [present/envisioned familial]:

Elsu: Our biggest challenge, our biggest commission on earth, is to ensure the salvation ... [to] ensure that our children are Christians.

\footnotetext{
${ }^{1}$ All participant names are pseudonyms
} 


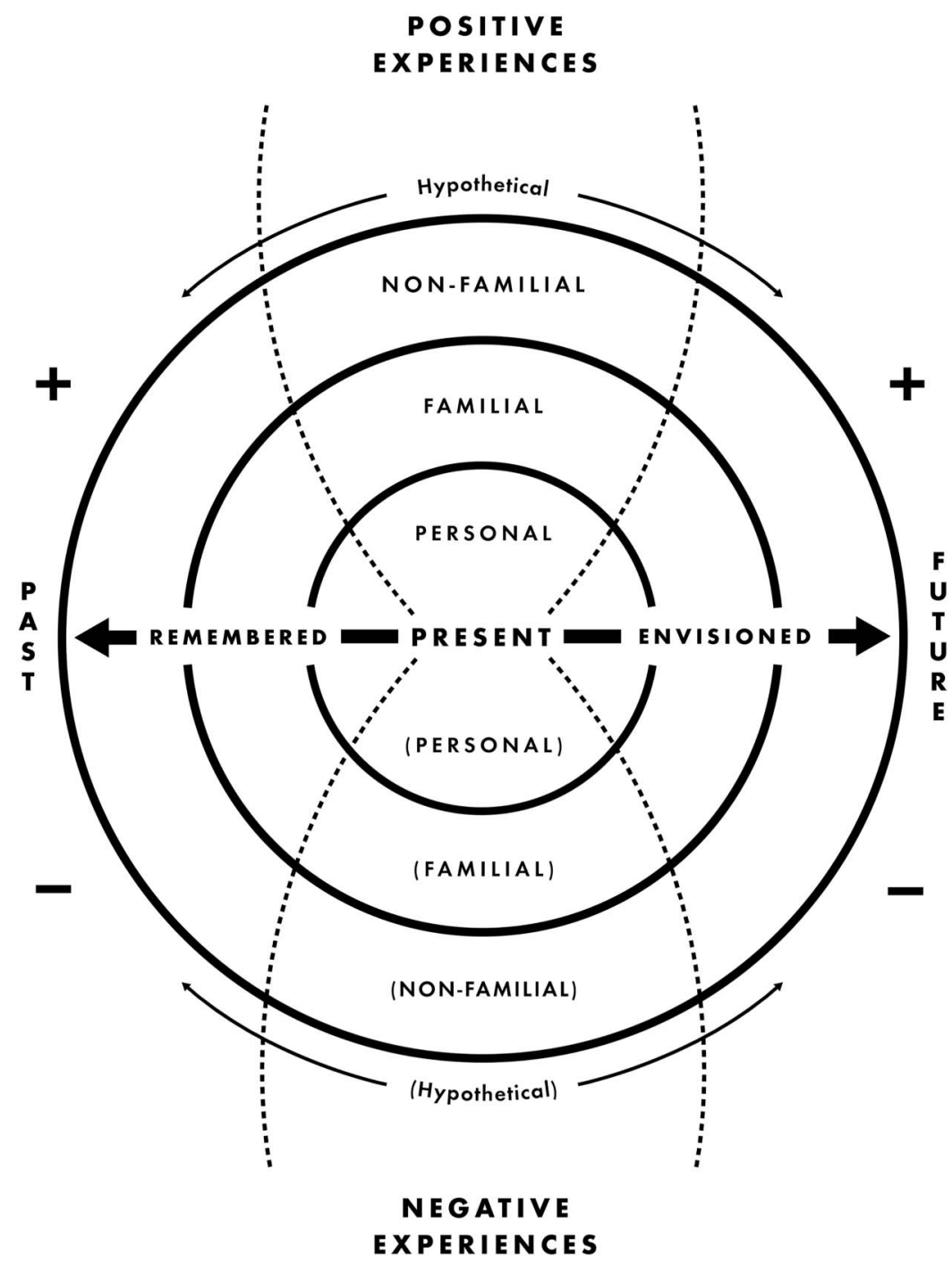

Figure 1. Conceptual model of experiential immediacy. Terms closer to the Negative Experiences "pole" are in parentheses to indicate they are negative in nature. The dashed lines radiating from "present" divide the three time periods. All experiences above the "equator" marked by the timeline are positive and all below are negative in nature.

Wachiwi: Because we [will be] held accountable for that, when it is all said and done.

Meng (husband) and Mei-Fen (wife), Chinese Christians, give another example of inadequacy, but instead of parenting, they refer to their marriage [remembered/present familial]:

\section{Mei-Fen (wife): A wife submits [to] her husband completely and a husband loves his wife completely. We could not do that, which is our sin. In God's eye, our $\sin [$ is] ... pride and jealous[y]. The marriage which God wants us to [have] is complete love and submission [to God].}

Meng (husband): We are insufficient.

The above accounts of feeling inadequate are among the 106 relating to being burdened (often by feelings of guilt or inadequacy). Next, we discuss the burdens-related struggle of obligations.
Obligations: "A heavy responsibility." The accounts in this subtheme differed slightly because their focus was not on an inability to live up to expectations, but seemed to be on the burdens felt because of the obligations religion placed on families. Many of the participants' accounts associated with this struggle used language including "difficult" or "heavy responsibilities." For example, Ali, an Arab American, Muslim father, explained [present personal], "Islam taught me that my children are not 'my' children. They are a gift from God, and He loaned them to me. And that's a heavy responsibility."

Candace, an Episcopalian mother, discussed how the burden of teaching religion to her children exerted pressure on herself [remembered personal]:

I have put a lot of pressure on myself to try to teach [religion].... The mistake that I have made in the past is trying to teach something that has to be experienced. . . . [I]n some ways, [doing so] created a counter to that ... a rebelliousness to that. 
Table 2

Frequency and Percentage of Accounts of Temporal Immediacy and Type of Relational Struggle

\begin{tabular}{|c|c|c|c|c|}
\hline \multirow[b]{3}{*}{ Type of struggle } & \multicolumn{4}{|c|}{ Temporal immediacy } \\
\hline & \multicolumn{2}{|c|}{ Actual experiences } & \multicolumn{2}{|c|}{ Possible experiences } \\
\hline & $\begin{array}{c}\text { Present } \\
N(\%)\end{array}$ & $\begin{array}{c}\text { Remembered } \\
N(\%)\end{array}$ & $\begin{array}{c}\text { Envisioned/ } \\
\text { Hypothetical } \\
N(\%)\end{array}$ & $\begin{array}{c}\text { Total } \\
N(\%)\end{array}$ \\
\hline Burdens & $64(23)$ & $19(7)$ & $23(8)$ & $106(38)$ \\
\hline Disunities & $28(10)$ & $30(11)$ & $39(14)$ & $97(34)$ \\
\hline Abuses & $17(6)$ & $13(4)$ & $32(11)$ & $62(22)$ \\
\hline Offenses & $9(3)$ & $8(3)$ & $0(0)$ & $17(6)$ \\
\hline Total & $118(42)$ & $70(25)$ & $94(33)$ & $282(100)$ \\
\hline
\end{tabular}

Note. $\quad N=$ number of accounts. Percentages are for each cell (except for totals). An assumption of chi-square tests is that observations are independent. This assumption was not met for these data as a number of the accounts come from the same participant. There were 119 families reflected in the 282 accounts. Therefore, the results of the chi-square tests reported below (and mentioned in the text) must be interpreted with great caution. In order to indicate lack of statistical certainty, in the text of the article we use the phrase "Chi-square tests suggest" (rather than "prove" or "confirm" or "indicate").

Overall Test of Relation. Overall $\chi^{2}(6, N=282)=41.00, p<.001$ indicating that Temporal Immediacy and Type of Struggle are significantly related.

Further Tests of Relation. We conducted two further tests. The first was to test whether present burdens were reported more often than expected. The second was to test whether envisioned/hypothetical abuses were reported more than expected. Both tests were significant at the $p<.05$ level. Type of Present Struggle (testing by first column). Finding: Present Burdens: $\chi^{2}(3, N=118)=8.70, p=.034$. Interpretation: Within the present struggles, burdens were reported significantly more often than expected. There were more than twice as many reported accounts of burdens (64) than any other present struggle.

Temporal Immediacy of Abuses (testing by third row). Finding: Envisioned/Hypothetical Abuses: $\chi^{2}(2, N=62)=6.22, p=.045$. Interpretation: With the abuses struggle, envisioned/hypothetical abuses were reported significantly more than expected. There were more than twice as many reported accounts of envisioned/hypothetical abuses (32) than either present or past abuses.

Some of those we interviewed sometimes felt that the religious teaching required of them was either unpleasant or difficult. Gabriella, a Conservative Jewish mother, said [present personal],

[One] challenge is that I have to teach our children about our history and [the] history of persecution. ... That's not something that I look forward to. I have talked to them about the Holocaust and those discussions will go on for a lifetime at different levels.

In addition to the obligation to teach, the "obligations" struggle often involved religion causing a family member to neglect the needs of another, such as when church assignments took time away from family. Yuan, a Chinese Christian husband, said [present familial], "Sometimes we have too much service. . . . It becomes a big burden, which may be harmful to a family. To be a good person ... outside, but to do nothing at home may be harmful to a marriage."

Aaron, a Lutheran husband and father, explained how a poor balance between church and family occasionally happened in their family [present familial]:

We struggle sometimes with being overcommitted in the churchwhere we're spending more time there or devoting our time there, rather than to each other and home life, at times.... We find ourselves getting so wrapped up into that. It's like a drug.

Having discussed the burdens struggle (with the subthemes of inadequacies and obligations), we now move on to another frequently reported struggle: disunities.

\section{Relational Struggle 2: Disunities}

Disunities experiences were coded in $34 \%$ of the within-family Relational Struggles Associated with Religion accounts. This struggle involved feeling in conflict with others or separated from others. We have divided the disunities accounts into two subthemes: conflict and separation. The subtheme of conflict will be discussed first.

Conflict: "Religion was the cause of these conflicts." Expressed struggles ranged from minor conflicts to divorce, and many of these conflicts seemed to stem from differing beliefs or religious opinions. For example, Fadilah, an Arab American, Shia Muslim, expressed how conflict arose due to differing beliefs in her own marriage [remembered familial]:

In our . . . ten years of marriage, the most tumultuous years were the first ... two and a half, and religion actually was the cause of these conflicts, because we have, in certain areas, quite different religious interpretations.

Others told about experiences of other family members. For example, Kordell, an African American Christian husband, explained [remembered familial],

\footnotetext{
My dad was not a believer. He pretended to be one 'till he married my mother and then he didn't go to church for the next 50 years. They were married for 50 years. So it was real difficult 'cause my mom was a preacher's kid. So she did everything she could and was successful to a certain degree [but] it was chaos. It was crazy.
}

Some participants mentioned religion-related conflict being a current issue. An Episcopal father and son expressed how differing opinions about the importance of going to church versus participating in sports had generated conflict in their family [remembered/present familial]:

Dustin (Dad): We would have a conflict there in this family.

Ryan (Son): My mom wants me to go to church, and my dad, depending on the sport, would want me to go to the sport. ... We'd be split and there'd be a brawl between them.

Having briefly explored the struggles about within family conflicts associated with religion, we now turn to a slightly different disunities struggle, which is a feeling of separation.

Separation: "We weren't on the same path." Another type of disunity was feeling separated from others. These accounts resemble the conflict accounts in that many of the challenges stem from having differing beliefs. However, these struggles do not focus on conflict. Rather, the main focus of this struggle is the difference itself. Miriam, a convert to Judaism, gave an example of separation between herself and her sister and brother-in-law because of differing religious beliefs [present familial]:

My [sister] will think that I've given up going to heaven. ... [She] is very religious, married to a very odd fanatical. I'm not sure what you 
would call his religion, but they would say that I have given up . . . salvation or going to heaven, because I do not believe Jesus is the Messiah. [They think] I've given up all hope of getting to heaven.

Religion-based disunity was not limited to extended family, it was often marital. Many couples stated that if a wife and husband had differing beliefs or levels of commitment, this can generate distance and disunity in the marriage. One husband expressed how different levels of commitment [past familial] "caused marriage stress, [and] there were disagreements, foot-dragging." Hannah, speaking to her Jewish husband, Eli, stated [remembered familial],

But was not this actually, without our knowing it, all part of Hashem's [God's] plan? ... You know, we didn't like it. We suffered, because we were unhappy, because we weren't on the same path, right? But obviously this was how it was intended to work itself out so that instead of you and me going divergent roads over it, we had to work together and find a place where we could be comfortable with each other and build a Jewish home together.

Having discussed the two subthemes of the disunities struggle (conflict and separation), we now move on to discuss the third struggle that emerged from our team's coding: abuses.

\section{Relational Struggle 3: Abuses}

Feelings captured and reflected in the abuses accounts included: inferiority, force, domination, abuse, threat, teasing, and persecution. The majority of these accounts were hypothetical (52\%), not experiential. Chi-square analyses (see Table 2) suggest that envisioned/hypothetical abuses were significantly more prevalent than expected. Whether attributable to lack of exposure to first-hand persecution, or reluctance to revisit painful experiences, or social desirability effects, actual experiences of abuse, domination, and persecution were not as frequently reported. Participants instead reported more nonfamilial, or hypothetical accounts of persecution or abuses from religion. Here, however, we will only provide accounts of experiences. We present the abuses accounts in two subthemes: domination and persecution.

Domination: "I was the king." Domination struggles included reports of feeling dominated, forced, inferior, or required to submit. The focus in these accounts seemed to be on issues of power, and mainly pertained to parent-child relationships or husband-wife relationships. The parent-child struggles primarily revolved around parents forcing their children to participate in religious activities. Abaan, an Arab American Muslim father, explained how they avoided this because of other poor examples they have seen [remembered nonfamilial]:

You do not want to force people to accept what you think is true. . . . Hopefully, we do it in a way that she [our daughter] enjoys it and she accepts it by heart. ... We have seen, in some settings, that the parents are very harsh, in terms of how they teach religion to children. . . . That environment is not accommodating toward children's needs and we do not believe that is how it is supposed to be done. . . Nobody can 'keep' their children in a religion.

Other accounts in the domination subtheme focused on husband-wife relationships. One example was given by Darrian, an African American Christian [remembered personal]:
I didn't see it. I guess initially I found myself at some point getting into a religious movement where it was becoming more ritualistic versus spiritual. [I believed] that this was god-ordained, that I was the leader, the priest, the king of the house, that I was called up to raise my children. I was the king [and I thought, "As] for me, and my house, we will serve the Lord."

In this case, the father suggested that he allowed his religious beliefs to motivate him to think that he held a position of sovereign authority. In retrospect, he regretted his previously overzealous and dominating attitude and behavior involving his approach to religion and family. With these examples offered, we now move from the domination subtheme to the persecution subtheme.

Persecution: "Be ready for the verbal attack." The persecution accounts focused on feeling attacked, harassed, teased, and/or manipulated. Although persecution may often come from outside the family, given the within-family focus of this article, we report only inside-family examples in which family members attacked or harassed other family members because of religion. For example, Malinda, a Charismatic Episcopalian, said [remembered/ present familial], "There's so many questions from so many family members ... [We have to] be ready for the verbal attack."

Other examples involved using religion as manipulation, such as the following from Jewish parents Zachary and Ruth. Zachary alluded to how this appeared in his childhood, and Ruth, somewhat tongue-in-cheek, revealed how this has appeared and does appear in her own parenting [remembered/present personal]:

Zachary: Well, I know one for me, a really specific one. I purposely do not use guilt as a motivator, and that probably comes from a reaction to my religious upbringing.

Ruth: Well, that's okay, because I'm filling in that void for you.

Having discussed the two subthemes (domination and persecution) of the abuses struggle, we now move to the fourth and final struggle: offenses.

\section{Relational Struggle 4 - Offenses: "It hurt my Parents."}

Reports of relational offenses, often associated with misunderstandings, were the struggles least often reported (only $6 \%$ of the total accounts) and were almost evenly divided between the present (9 accounts, 53\%) and the past (8 accounts, 47\%). Unlike the other three types of relational struggles, all accounts were of actual experiences (i.e., there were no reports of envisioned/hypothetical experiences). These accounts typically involved extended family members outside the faith or with divergent beliefs and practices from the interviewed participants. Accounts coded as offenses varied but often reflected emotional pain resulting from insensitivity, misunderstanding, judgment, or perceived violations-including sharp differences in religious belief or practice. Seth, a Jewish husband, reported [remembered familial]:

(Two of my brothers) married persons out of the faith and I do not think they'll have much religion of any sort now. . . . I mean, my parents love them very much but it hurt my parents. 
Seth later explained, [present familial] "When we are all sitting around at the [ritual-filled] holidays. ... There's a certain framework for life and marriage in Judaism . . . they [non-Jewish family members] just don't get it." These accounts indicate that offense, or at least emotional pain, likely was experienced by multiple members of the extended family in such contexts-including not only Seth and his parents, but also his brothers and their wives. Whether intended or incidental, the struggles of pain and offense can be associated with religion within families.

\section{Discussion of Relational Struggles}

We conducted in-depth interviews with 198 highly religious, ethnically and racially diverse families ( $N=476$ individuals) from all eight regions of the United States. Using a rigorous system of team-based analysis, we coded the interviews for accounts of religiously associated relational struggles within families. We identified four kinds of relational struggles: burdens, disunities, abuses, and offenses. We also identified two major types of experiential immediacy: (a) actual experiences (ongoing experiences and/or remembered struggles involving self, family members, or others) and (b) possible experiences (envisioned and hypothetical struggles). Next we discuss the four major types of struggles in relation to previous scholarship, then we discuss experiential immediacy, followed by implications for further research, particularly how our concept of experiential immediacy may assist scholars conceptualize and explore human experience.

\section{Types of Struggles}

In relation to the literature on religious and spiritual struggles, three of the four struggles we identified seem to be interpersonal struggles-disunities, abuses, and offenses. The exception was burdens, which we will discuss in the intrapersonal section. The purpose of the study was originally to find relational struggles, so it is not surprising that the majority of our findings seemed to fall into the interpersonal domain.

Interpersonal. The disunities struggle involved differing religious beliefs creating conflicts. This struggle was the most frequently mentioned of the interpersonal struggles, indicating that many religious families often struggle with certain kinds of disunities, such as religiously oriented conflicts and separations.

The abuses struggle, the second most frequent interpersonal struggle, involved feeling dominated, forced, inferior, or required to submit. Other research has indicated that some applications of husband "headship" and wife "submission" as taught in a few verses of the New Testament may evoke marital challenges (Bartkowski, 1997; Lu, Marks, \& Baumgartner, 2011).

Most (52\%) of the 62 coded accounts of abuses were hypotheticals and $48 \%$ were actual experiences in a family's own past $(21 \%)$ or present $(27 \%)$. It is possible (even probable) that there were more experiences of abuse that occurred, but were not reported due to social desirability effects. Likewise, some "hypothetical" examples may have been veiled reports of actual abuseoriented struggles that were framed as hypothetical to protect privacy.

The offenses struggle, the least frequently mentioned interpersonal struggle, was often reportedly associated with misunderstandings. These accounts often involved family members outside the faith failing to understand the beliefs and practices of the interviewed family. In Exline's (2013) recent review of the religious struggles literature, she identified two main types of interpersonal struggles-(a) disagreements about religious issues and (b) offenses by members of religious groups. The former seems to correlate well with the disunities struggle we have identified. The latter seems to correlate with the offenses struggle we have identified. However, much of the literature on offenses has focused on offenses between members of a congregation, instead of within families. Offense with fellow congregants is explored more in an article about outside-family religious relational struggles (Marks, Dollahite, \& Young, 2017).

Intrapersonal struggles. The burdens struggle was the only one that seemed primarily intrapersonal in nature. It may be surprising that any intrapersonal struggles would be discovered when looking specifically for relational struggles. The burdens described typically revolved around a fear of failure to live up to certain standards concerning how to behave in relationships. Sources of this struggle may have been fear of sin or eternal punishment-indeed many of these quotes referred to the idea of being held accountable to God for living up to (or failing to meet) certain standards. In relation to the literature on religious struggles, the burdens struggle seems to correlate most closely with Exline's domain of moral struggles (Exline \& Rose, 2013).

Personal and familial experiences. Much of the literature on religious and spiritual struggles has addressed the individualsuch as an individual's troubled relationship with God, an individual's own personal religious doubts, or an individual's troubled relationship with another person. However, our data highlight that a relationship, such as a married couple, or a family unit can have various religious struggles, both interpersonal and intrapersonal. Many of the quotes in the burdens section, which seem to correlate with intrapersonal struggles, still used the language of "we" and "our." Interpersonal struggles do not necessarily just involve one person with another person, but could involve a whole family with another person, a whole family with multiple persons, or other dyadic or group-level interactions (Exline \& Rose, 2013).

\section{Experiential Immediacy: Conceptual Framework and Implications for Research}

In this section, we present a conceptual framework based on our (documented) analyses of the way that participants spoke about religion-based relational struggles in their families. We first discuss the genesis of the idea of what we call experiential immedi$a c y$, then we present the concepts that make up the framework, discuss our conceptual model (see Figure 1), and finally discuss the implications of this framework for future research.

\section{Genesis of Experiential Immediacy}

Among our highly religious participants, relational struggles associated with religious beliefs, practices, and communities were not always easy to evoke or elicit. Both interviewers and participants had likely experienced mostly positive outcomes from religious involvement so were on less familiar ground discussing struggles. As we wrestled with the ways that our participants addressed this issue, we came up with a new way to think about how people spoke of difficult experiences in their lives. We 
noticed that people spoke of experiences that occurred to them personally, or to family members, and to others outside their family. They provided accounts of past (remembered) and present experiences. Accounts differed in whether they addressed positive or negative experiences (most accounts of experiences in our data are positive but this article deals with struggles-negative experiences). Participants also sometimes provided envisioned or hypothetical examples of possible struggles. We decided that it was valuable to consider these accounts as different types and degrees of what we call experiential immediacy. Specifically, in the accounts we analyzed, we noticed and coded two types of experiential immediacy: actual experiences and possible experiences. Within the experiences were different kinds and degrees of experiential immediacy. Next we discuss the concepts that make up the experiential immediacy framework. To illustrate how these concepts are related, we constructed a conceptual model (see Figure 1).

\section{Actual Experiences (Present and Remembered)}

Actual experiences. Actual experiences were accounts of occurrences of religion creating relational struggles in the present or past. Actual experiences differed on the degree of temporal immediacy based on temporal proximity (proximity to the present). The greatest experiential immediacy was reflected by accounts of experiences happening now (present experiences). Experiential immediacy decreased as participants' experiences moved away from the present into the past (remembered experiences) or into a possible future (envisioned experiences).

Present experiences. Present experiences were accounts of religion creating struggles in the participants' current lives. These experiences had the greatest experiential immediacy in that they were occurring and were more present/immediate than whatever may have occurred in the past or might be imagined to occur in the future.

Remembered experiences. Accounts of remembered experiences involved accounts of religion having generated struggles in the participants' past that are no longer being experienced. Experiences from the past (particularly if traumatic) can have great impact on one's life and there was no simple relationship between experiential immediacy and psychological or relational impact or influence. (Distant past experiences can fade or remain salient in the present).

\section{Possible Experiences (Envisioned and Hypothetical)}

Participants reported two kinds of possible experiences we call envisioned experiences and hypothetical experiences.

Envisioned experiences. Envisioned experiences were those that participants or their family members envisioned, imagined, and hoped or planned could/would occur in their future. Envisioned experiences went beyond mere casual wishing or daydreaming; they were deeply held and envisioned experiences that were emotionally or spiritually potent enough to influence action in the present. The potential power of envisioned experiences supports the observation of W. I. Thomas (1923) that a situation perceived as real is real in its consequences. Although many envisioned experiences were positive in nature (e.g., envisioning a child marrying in the faith to a wonderful person) they could be negative (envisioning a child leaving the faith).
Hypothetical experiences. Hypothetical experiences (also called hypotheticals herein) were examples of possible struggles that religion could generate that did not rise to the level of an envisioned experience. Hypotheticals dealt with possible past, present, and/or future positive or negative situations. An example of a hypothetical about the past was: "If I had been abused by a religious leader, as some have, I probably would not be religious now." An example of a hypothetical struggle about the present was: "Given our marital difficulties, if we were not religious, we would likely divorce." An example of a hypothetical struggle about the future was: "If our child were to leave our faith we would be devastated." In Figure 1, hypotheticals may concern the past, present, or future and so are placed at a distance from present, remembered, and envisioned experiences and straddle the temporal dimensions of past-present and present-future.

Many hypotheticals were expressed in response to the question, "Do you feel that there are any religious beliefs or practices that if misunderstood or misapplied can be harmful?" Few hypotheticals were spontaneously expressed. Herein we focus on actual experiences by exploring actual struggles more than envisioned or hypothetical ones.

\section{Temporal Proximity}

Time is experienced differently by different people and can seemingly slow down or speed up based on various factors. Further, time is often combined with emotional experience in fascinating ways. For example, part of present experience is what we call remembered experience, which includes experiences that occurred in the past but continue to remain "alive" and perhaps even influential in the present through memory and storytelling by the participant, the family, or friends. Similarly, envisioned experiences occurred in the present but usually centered on possible experiences in the future. In Figure 1, remembered and envisioned experiences are placed between two time frames (past-present for remembered and present-future for envisioned). In the figure, dashed lines divide experiences into remembered past, present, and envisioned future. Remembered, present, and envisioned experiences are distinct in some ways, but the dashed lines symbolize the inherent fluidity of time. Six categories of experiential quality (positive or negative) are remembered positive or negative, present positive or negative, and envisioned positive or negative.

\section{Personal Proximity}

The other type of proximity that makes up experiential immediacy is what we call personal proximity (proximity to the person). The three spheres of proximity include personal, familial, and nonfamilial. Personal experiences were experienced by the participant. Familial experiences were experienced by someone in the participant's immediate or extended family. Nonfamilial experiences are accounts told about others with whom the family is affiliated. Figure 1 represents these three spheres of proximity with concentric circles with personal at the center, familial in the middle, and nonfamilial on the outside. In terms of experiential immediacy, personal present is the most immediate kind of experience, since it is at the nexus of the two dimensions of experiential immediacy (temporal and personal proximity). 


\section{Quality of Experience}

Baumeister, Bratslavsky, Finkenauer, and Vohs (2001) have shown that negative experiences are "stronger" (more powerful and salient) than positive experiences in a variety of ways-and that profoundly negative experiences can have long-term, even lifelong impacts. Because our article deals with relational struggles which were typically described as at least somewhat negative in nature, we believe it is important to include this dimension in our conceptualization of experiential immediacy.

One reason bad experiences are stronger than good ones is that they linger across time and influence people well beyond the experience. We think attending to experiential immediacy will better fulfill the potential of qualitative research in understanding experience. We categorize accounts of experiences as either positive and negative (some may be both). Based on our data, we posit that profoundly positive or negative experiences likely are more influential on relationships than moderately or slightly positive or negative ones. Although some participants described profoundly negative struggles, most of the reported experiences fall into the somewhat-to-moderately negative center of that continuum, although participants often reframed negative experiences (struggles) in positive ways.

\section{Implications of the Experiential Immediacy Framework for Research}

Next we discuss ideas about how this model could be used by scholars to conceptualize and measure human experience.

Questions about remembered, present, and possible experiences. A claim of qualitative research is that the method can be tailored to capture "video" across time rather than the "snapshots" provided by most cross-sectional quantitative research (Marks, 2015). We concur with Daly (2004) that greater attention should be paid to the temporal dimension of family life and we propose that greater sensitivity to remembered, present, and possible experiences during development of qualitative interview schedules would be helpful. It may be especially important to attend to these matters when asking about potentially sensitive topics, however the core issues seem to apply to many, if not most, qualitative projects. We suggest that scholars consider experiential immediacy across time in all aspects of their research projects.

In our interviews, we asked questions that addressed past, present, and possible experiences. Questions about the past included, "Did your religious beliefs influence how you met and decided to marry?" A question that bridged past and present was "Have you influenced each other's initial or ongoing involvement with your faith?" Questions about the present included, "Are there ways that your beliefs or practices help avoid or reduce marital conflict?" A question that bridged present and possible was "What are the greatest obstacles (external or internal) to your marriage being all that you and God want it to be?" Questions that addressed the future included (to youth) "Does your religion influence how you think about your future marriage and family life?" To obtain richer accounts of lived experience, after many of these questions we asked "Can you share a specific example of what you were just discussing?"

We believe that examining the level of experiential immediacy in qualitative data is helpful. It may also be helpful to ask about envisioned experiences and hypotheticals that may be relevant to the research question. It is possible that the more immediate an experience shared by a research participant is, the more likely that experience will be a valid and reliable indicator of the power of that experience. Present, salient experiences are likely to be immediately influential in a person's or family's life. Of course, past salient experiences can also influence present thoughts, feelings, and actions. Further, powerfully envisioned future experiences can be influential in directing current activities. Each of these possibilities may be worth exploring during instrument development, data collection, and data analysis.

\section{Implications of the Present Study for Future Research}

There are some implications of the present study for future research.

\section{Why Do They Stay?}

Eighty-nine percent of the religious families we interviewed had at least one coded account of a relational struggle associated with religion, and the average number of coded accounts of struggles was 8.3 per family. Interestingly, most families in our sample had self-selected to be highly involved in their faith communities, devoting significant time, energy, and money to their religion (Marks, Dollahite, \& Baumgartner, 2010). Thus, these families confirm the proposition that even many relatively happy and functional families of faith (i.e., exemplars) experience relational struggles - and some are generated or exacerbated by religion.

Most people would understandably try to avoid the struggles we have studied. Yet our data indicate that the vast majority of the families in our sample (89\%) reportedly have experienced and/or do experience them. Why do these families choose to remain actively religious if doing so is associated with relational struggles? One explanation may be that our data (not reported) demonstrate that religion both generates and addresses (and may even resolve) a variety of struggles, including relational ones. Religious beliefs, practices, and communities offer various ways for adherents to frame and understand trials and afflictions: a punishment for sin, a crucible that purges baser motives, a way to learn humility, a path to holiness, a way to show love to God, or a way to develop moral virtues, among other possibilities and interpretations (Prothero, 2010).

Thus, any and all of the relational struggles we have studied may have religious meanings and values in addition to any relational problems or benefits that accompany those struggles. Indeed, research has indicated that religion can provide much in the way of coping (see Gall \& Guirguis-Younger, 2013). However, another interesting duality may be that religious struggles not only harm relationships, but generate relational benefits as well. Exploring the harms and benefits of relational struggles associated with religion may help explain why many families remain religiously involved despite struggles that are reportedly associated with religion.

\section{Outside the Family Struggles}

Now that we have investigated relational struggles associated with religion within the family, we are also focusing on the types 
of relational struggles associated with religion outside the family. Future research should also examine the possible benefits of these types of struggles, as well as ways that religious beliefs, practices, and communities help families address and resolve religious struggles. It would also be interesting to explore why religious beliefs, practices, and communities seem to generate these and other struggles. Is it simply that religions teach that God requires people to be better than they are (e.g., to "repent and sin no more")? Do religious communities engender comparisons with other highly religious people, leading to a variety of comparison-based struggles?

\section{Limitations}

This study is subject to the limitations of many qualitative research studies. Although the sample is unusually large $(N=476)$ and geographically diverse (i.e., national) for a qualitative study, it is neither random nor representative. Further, although the sample is ethnically and religiously diverse, only American families in the Abrahamic faiths were interviewed. Two factors likely led to an underreporting of relational struggles. First, because we only interviewed families involved in their faith communities, we did not hear from those for whom the number and/or severity of relational struggles caused by religion was enough to led to disassociation from their faith community (such participants would offer another direction for future research). Second, the presence of social desirability likely limited the number and kinds of struggles that participants were willing to mention during the interviews.

\section{Conclusion: Reflexivity Reprised}

Daly (2004) called for study of the "negative spaces" of family life, by which he meant aspects of family that are often invisible in scholarship. Mahoney (2010) called for increased study of ways that religion can do harm in families. This study addressed three negative spaces (religion, daily experiences, and time) and focused on potentially negative influences of religion on family relationships. This study has confirmed our developing sense of the imperative to systematically explore the negative or darker side of religion on family life. Even highly religious families experience a range of relational struggles that are to some extent generated or exacerbated by religious involvement, and there is real value in attending to these struggles.

Understanding the types of struggles that may come from high religious involvement is important so that families can navigate and resolve struggles in such a way that relationships not only endure but are strengthened and enhanced. Perhaps the strength found in navigating and resolving these relational struggles may help unify families rather than divide them. Helping religious individuals, couples, and families find ways to approach and practice their faith in ways that minimize the creation of excessive or harmful relational struggles can have positive benefits for adults and children across generations. We also hope this study contributes to the ongoing rapprochement between religion and science as those in both fields increase their abilities to see the strengths and limitations of each domain and engage in mutually respectful dialog.

\section{References}

Abu-Raiya, H., \& Pargament, K. I. (2015). Religious coping among diverse religions: Commonalities and divergences. Psychology of Religion and Spirituality, 7, 24-33. http://dx.doi.org/10.1037/a0037652

Abu-Raiya, H., Pargament, K. I., Krause, N., \& Ironson, G. (2015). Robust links between religious/spiritual struggles, psychological distress, and well-being in a national sample of American adults. American Journal of Orthopsychiatry, 85, 565-575. http://dx.doi.org/10.1037/ort0000084

Babbie, E. (2004). The practice of social research (10th ed.). Belmont, CA: Wadsworth.

Bartkowski, J. P. (1997). Debating patriarchy: Discursive disputes over spousal authority among Evangelical family commentators. Journal for the Scientific Study of Religion, 36, 393-410. http://dx.doi.org/10.2307/ 1387857

Baumeister, R. F., Bratslavsky, E., Finkenauer, C., \& Vohs, K. D. (2001). Bad is stronger than good. Review of General Psychology, 5, 323-370. http://dx.doi.org/10.1037/1089-2680.5.4.323

Bengtson, V. L., Putney, N. M., \& Harris, S. (2013). Families and faith: How religion is passed down across generations. New York, NY: Oxford. http://dx.doi.org/10.1093/acprof:oso/9780199948659.001.0001

Burr, W. R., Marks, L. D., \& Day, R. (2012). Sacred matters: Religion and spirituality in families. New York, NY: Routledge.

Bushman, B. J., Ridge, R. D., Das, E., Key, C. W., \& Busath, G. L. (2007). When god sanctions killing: Effect of scriptural violence on aggression. Psychological Science, 18, 204-207. http://dx.doi.org/10.1111/j.14679280.2007.01873.x

Curtis, K. T., \& Ellison, C. G. (2002). Religious heterogamy and marital conflict. Journal of Family Issues, 23, 551-576. http://dx.doi.org/10 $.1177 / 0192513$ X02023004005

Daly, K. (2004). Family theory versus the theories families live by. Journal of Marriage and Family, 65, 771-784. http://dx.doi.org/10.1111/j.17413737.2003.00771.x

Daly, K. (2007). Qualitative methods for family studies and human development. New York, NY: Sage.

Denzin, N. K., \& Lincoln, Y. S. (Eds.). (1994). Handbook of qualitative research. Thousand Oaks, CA: Sage.

Dollahite, D. C., Marks, L. D., \& Young, K. P. (in press). How Religion helps and harms: Duality and divergent outcomes at the nexus of faith and family life. Journal of Family Theory and Review.

Ellison, C. G., Bartkowski, J. P., \& Segal, M. L. (1996). Conservative Protestantism and the parental use of corporal punishment. Social Forces, 74, 1003-1028. http://dx.doi.org/10.2307/2580390

Ellison, C. G., \& Lee, J. (2010). Spiritual struggles and psychological distress: Is there a dark side of religion? Social Indicators Research, 98, 501-517. http://dx.doi.org/10.1007/s11205-009-9553-3

Exline, J. J. (2013). Religious and spiritual struggles. In J. J. Exline, K. I. Pargament, J. W. Jones, K. I. Pargament, J. J. Exline, \& J. W. Jones (Eds.), APA handbook of psychology, religion, and spirituality: Vol. 1. Context, theory, and research (pp. 459-475). Washington, DC: American Psychological Association.

Exline, J. J., Pargament, K. I., Grubbs, J. B., \& Yali, A. M. (2014). The Religious and Spiritual Struggles Scale: Development and initial validation. Psychology of Religion and Spirituality, 6, 208-222. http://dx .doi.org/10.1037/a0036465

Exline, J. J., \& Rose, E. D. (2013). Religious and spiritual struggles. In R. F. Paloutzian \& C. L. Park (Eds.), Handbook of the psychology of religion and spirituality (2nd ed., pp. 380-398). New York, NY: Guilford Press.

Gall, T. L., \& Guirguis-Younger, M. (2013). Religious and spiritual coping: Current theory and research. In K. I. Pargament, J. J. Exline, \& J. W. Jones (Eds.), APA handbook of psychology, religion, and spirituality: Vol. 1. Context, theory, and research (pp. 349-364). Washington, DC: American Psychological Association. http://dx.doi.org/10.1037/14045019 
Gunnoe, M. L., Hetherington, E. M., \& Reiss, D. (1999). Parental religiosity, parenting style, and adolescent social responsibility. The Journal of Early Adolescence, 19, 199-225. http://dx.doi.org/10.1177/ 0272431699019002004

Handel, G. (1996). Family worlds and qualitative family research. Marriage \& Family Review, 24, 335-348. http://dx.doi.org/10.1300/ J002v24n03_06

Holmberg, D., Orbuch, T. L., \& Veroff, J. (2004). Thrice told tales: Married couples tell their stories. Mahwah, NJ: Erlbaum.

Koenig, H. G., King, D. E., \& Carson, V. B. (2012). Handbook of religion and health (2nd ed.). New York, NY: Oxford.

Krause, N., Chatters, L. M., Meltzer, T., \& Morgan, D. L. (2000). Negative interaction in the church: Insights from focus groups with older adults. Review of Religious Research, 41, 510-533. http://dx.doi.org/10.2307/ 3512318

Lee, J. W., Rice, G. T., \& Gillespie, V. B. (1997). Family worship patterns and their correlation with adolescent behavior and beliefs. Journal for the Scientific Study of Religion, 36, 372-381. http://dx.doi.org/10.2307/ 1387855

Lu, Y., Marks, L. D., \& Apavaloiae, L. (2012). Chinese immigrant families and Christian faith community. Family and Consumer Sciences Research Journal, 41, 118-130. http://dx.doi.org/10.1111/fcsr.12002

Lu, Y., Marks, L. D., \& Baumgartner, J. (2011). "The compass of our life": A qualitative study of marriage and faith among Chinese immigrants. Marriage \& Family Review, 47, 125-148. http://dx.doi.org/10.1080/ 01494929.2011.571633

Mahoney, A. (2010). Religion in families 1999 to 2009: A relational spirituality framework. Journal of Marriage and Family, 72, 805-827. http://dx.doi.org/10.1111/j.1741-3737.2010.00732.x

Mahoney, A. (2013). The spirituality of us: Relational spirituality in the context of family relationships. In K. I. Pargament, J. J. Exline, J. W. Jones, K. I. Pargament, J. J. Exline, \& J. W. Jones (Eds.), APA handbook of psychology, religion, and spirituality: Vol. 1. Context, theory, and research (pp. 365-389). Washington, DC: American Psychological Association. http://dx.doi.org/10.1037/14045-020

Mahoney, A., Pargament, K. I., Tarakeshwar, N., \& Swank, A. B. (2001). Religion in the home in the 1980s and 1990s: A meta-analytic review and conceptual analysis of links between religion, marriage, and parenting. Journal of Family Psychology, 15, 559-596. http://dx.doi.org/10 $.1037 / 0893-3200.15 .4 .559$

Marks, L. (2015). A pragmatic, step-by-step guide for qualitative methods. Current Psychology, 34, 494-505. http://dx.doi.org/10.1007/s12144015-9342-x

Marks, L. D., \& Dollahite, D. C. (2011). Mining the meanings and pulling out the processes from psychology of religion's correlation mountain. Psychology of Religion and Spirituality, 3, 181-193. http://dx.doi.org/ 10.1037/a0022206

Marks, L. D., \& Dollahite, D. C. (2017). Religion and families: An introduction. New York, NY: Routledge.

Marks, L. D., Dollahite, D. C., \& Baumgartner, J. (2010). In God we trust: Qualitative findings on finances, family, and faith from a diverse sample of U.S. families. Family Relations: An Interdisciplinary Journal of Applied Family Studies, 59, 439-452. http://dx.doi.org/10.1111/j.17413729.2010.00614.x

Marks, L. D., Dollahite, D. C., \& Young, K. P. (2017). Strangers in their own land: Struggles experienced by U.S. religious-ethnic minority families. Unpublished manuscript.

McConnell, K. M., Pargament, K. I., Ellison, C. G., \& Flannelly, K. J. (2006). Examining the links between spiritual struggles and symptoms of psychopathology in a national sample. Journal of Clinical Psychology, 62, 1469-1484. http://dx.doi.org/10.1002/jclp.20325

Pargament, K. I. (2002). The bitter and the sweet: An evaluation of the costs and benefits of religiousness. Psychological Inquiry, 13, 168-181. http://dx.doi.org/10.1207/S15327965PLI1303_02

Pargament, K. I. (2013). Introduction. In K. I. Pargament, J. J. Exline, \& J. W. Jones (Eds.), APA handbook of psychology, religion, and spirituality: Vol. 1. Context, theory, and research (pp. xxiii-xxvii). Washington, DC: American Psychological Association.

Pargament, K. I., Mahoney, A., Exline, J. J., Jones, J. W., \& Shafranske, E. P. (2013). Envisioning an integrative paradigm for the psychology of religion and spirituality. In K. I. Pargament, J. J. Exline, \& J. W. Jones (Eds.), APA handbook of psychology, religion, and spirituality: Vol. 1. Context, theory, and research (pp. 3-19). Washington, DC: American Psychological Association. http://dx.doi.org/10.1037/14045-001

Prothero, S. (2010). God is not one. New York, NY: HarperOne.

Robinson, L. C., \& Blanton, P. W. (1993). Marital strengths in enduring marriages. Family Relations: An Interdisciplinary Journal of Applied Family Studies, 42, 38-45. http://dx.doi.org/10.2307/584919

Sacks, J. (2015). Not in God's name: Confronting religious violence. New York, NY: Schocken.

Seymour, J., Dix, G., \& Eardley, T. (1995). Joint accounts: Methodology and practice in research interviews with couples. New York, NY: Social Policy Research Unit, University of York.

Silk, M., \& Walsh, A. (2011). One nation, divisible: How regional religious differences shape American politics (Religion by Region series, Vol. 9). Lanham, MD: Rowman \& Littlefield.

Simonič, B., Mandelj, T., \& Novsak, R. (2013). Religious-related abuse in the family. Journal of Family Violence, 28, 339-349. http://dx.doi.org/ 10.1007/s10896-013-9508-y

Stark, R. (2012). America's blessings: How religion benefits everyone, including atheists. West Conshohocken, PA: Templeton.

Stokes, C. E., \& Regnerus, M. D. (2009). When faith divides family: Religious discord and adolescent reports of parent-child relations. Social Science Research, 38, 155-167. http://dx.doi.org/10.1016/j.ssresearch .2008 .05 .002

Thomas, W. I. (1923). The unadjusted girl: With cases and standpoint for behavior analysis. Boston, MA: Little, Brown and Co.

Received September 28, 2016

Revision received February 4, 2017

Accepted March 6, 2017 